\title{
Working Group on Arctic climate during the last two millennia
}

\section{NaLAN Koc}

Norwegian Polar Institute, University of Tromsø, Norway; nalan.koc@npolar.no

A main conclusion of the Intergovernmental Panel on Climate Change (IPCC) Fourth Assessment Report, 2007 is that the warming of the climate system is unequivocal, as is evident from observations of increases in global average air and ocean temperatures, widespread melting of snow and ice, and rising global mean sea level. Furthermore, most of the observed increase in globally averaged temperatures since the mid-20th century is very likely due to the observed increase in anthropogenic greenhouse gas concentrations. Warming in the Arctic is double that for the globe, both from the 19th to 21st century and from the late 1960's to the present. This amplification in the Arctic is due to a complex interplay between land, ice sheets, ocean and atmosphere, and is not fully understood.

Because climate models disagree on the relative amount of warming to be ex-

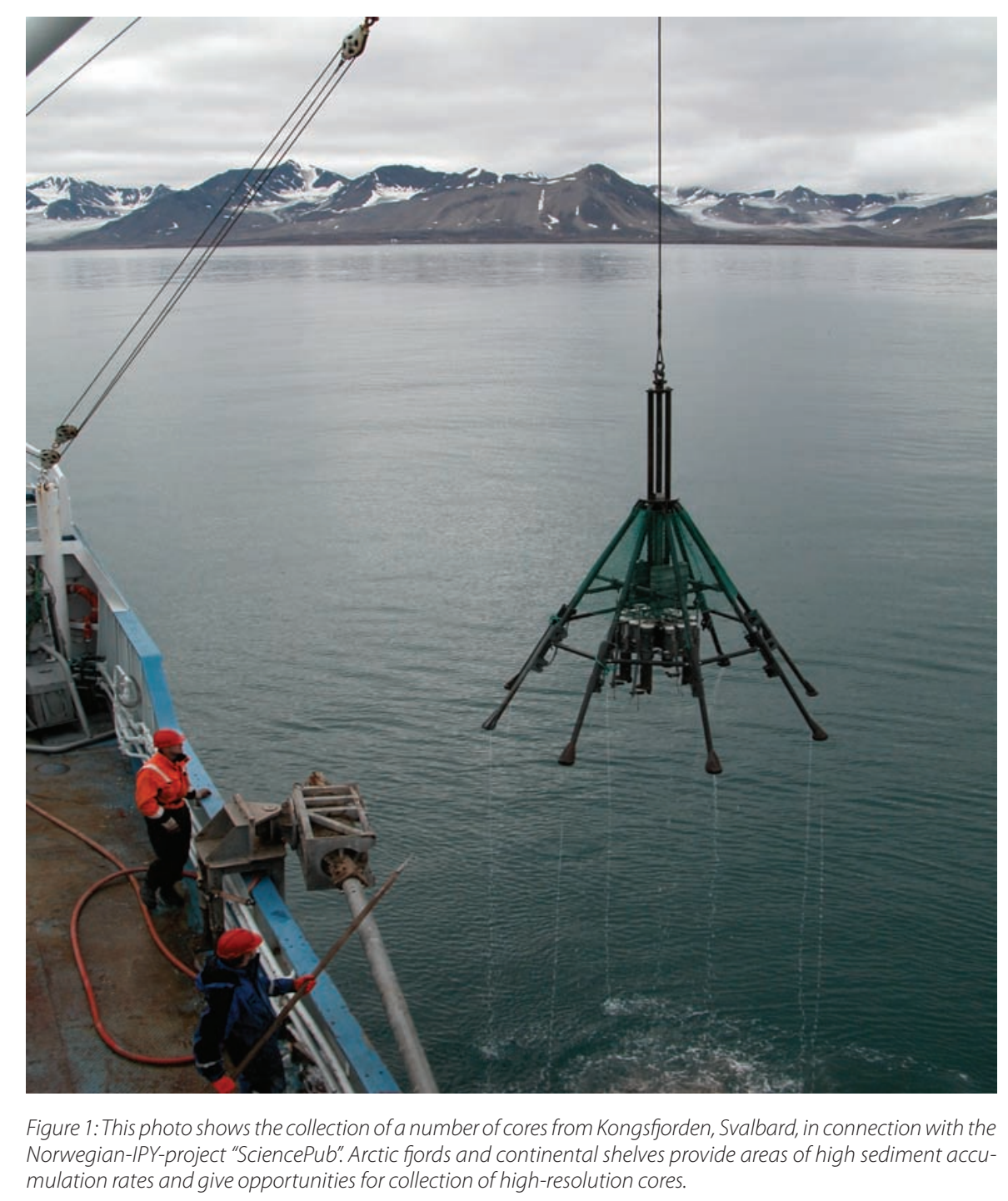

Figure 1: This photo shows the collection of a number of cores from Kongsfjorden, Svalbard, in connection with the Norwegian-IPY-project "SciencePub". Arctic fjords and continental shelves provide areas of high sediment accumulation rates and give opportunities for collection of high-resolution cores.

pected and natural variability adds further uncertainty, the future implications for society of these changes are unclear. The concern, though, is that human-induced climate change is accelerating and that the changes in the Arctic may have global, regional and local effects that challenge human society. The natural climate variability component of the system can be studied indirectly through past climate changes.

Changes in sea ice and tundra surface conditions, and changes in heat fluxes to and from the ocean, contribute to internal feedbacks and multi-year memory in the Arctic climate system. The patterns observed in the second half of the 20th century could be associated with two major atmospheric circulation patterns, the Arctic Oscillation (AO) and Pacific North American (PNA) indices. Large, natural atmospheric variability, as represented in part by the $A O$ and PNA, can result in multi-year persistence of Arctic climate patterns. The long-term history of these regional dynamic patterns can be mapped by paleoclimate proxies.

About $25 \%$ of the Arctic surface air temperature trend from 1979 to 2001 in winter and spring is related to an increase in the amount of net atmospheric northward energy transport across the $60^{\circ} \mathrm{N}$ latitude circle, with the strongest linkage in the Atlantic sector. What was the long-term influence of mid-latitude atmospheric circulation on Arctic climate, and how did it change during, for example, the Little Ice Age and the Medieval Warm Period? Another question is whether natural climate variability in the Arctic in the past was also generally amplified in comparison with mid-latitudes.

PAGES Working Group on arctic climate during the last two millennia is a new initiative to generate and synthesize highresolution paleoclimate data to assess and elucidate both the timing and variability of the Arctic climate change during this period. The group will especially work towards contributing to the series of regional reconstructions of the last 2000 years in the new PAGES Focus 2 "Regional climates and modes of variability".

All paleoclimate scientists working in the Arctic with high-resolution data and/ or modeling are welcome to join and contribute to this Working Group. Please express your interest through email to Nalan. koc@npolar.no. The first Working Group meeting will be held in connection with the Arctic Workshop in March 2008.

\section{References}

S. Solomon, D. Oin, M. Manning, Z. Chen, M.C. Marquis, K. Averyt, M. Tignor and H.L. Miller (Eds), 2007: Climate Change 2007: The Physical Science Basis. Contribution of Working Group 1 to the Fourth Assessment Report of the Intergovernmental Panel on Climate Change, Intergovernmental Panel on Climate Change, Cambridge and New York.

Richter-Menge, J., Overland, J., Proshutinsky, A., Romanovsky, V., Bengtsson, L., Brigham, L., Dyurgerov, M., Gascard, J.C., Gerland, S., Graversen, R. Haas, C, Karcher, M., Kuhry, P., Maslanik, J, Melling, H., Maslowski, W., Morison, J., Perovich, D., Przybylak, R., Rachold, V., Rigor, I., Shiklomanov, A., Stroeve, J., Walker, D. and Walsh J., 2006: State of the Arctic Report, NOAA OAR Special Report, NOAA/OAR/PMEL, Seattle, WA, 36 pp. 